${ }^{1}$ North-Western State Medical University named after I.I. Mechnikov, Department of Therapy, Rheumatology, Examination of Temporary Disability and Quality of Medical Care named after E.E.Eichwald, St. Petersburg, Russian Federation

Background: Cardiovascular risk (CVR) in patients (pts) with axial spondyloarthritis (axSpA) exceed the populational level. However, it remains unclear, which of the cardiovascular risk assessment systems is the most accurate in cases of chronic inflammation..

Objectives: of the current study were to assess the CVR in pts with axSpA and to compare different cardiovascular risk scales in these pts.

Methods: The study included 118 patients at the age of 25-65 years with diagnosis of axSpA fulfilling ASAS criteria (2009) from St. Petersburg' axSpA register. Three indices of cardiovascular risk evaluation (Systematic COronary Risk Evaluation (SCORE) with increasing coefficient 1.5 for inflammatory diseases, Reynolds Risk Score (RRS), and the third modification of QRESEARCH Cardiovascular Risk Algorithm (QRISK3) were calculated. For the pts below 40 years old only QRISK3 was calculated.

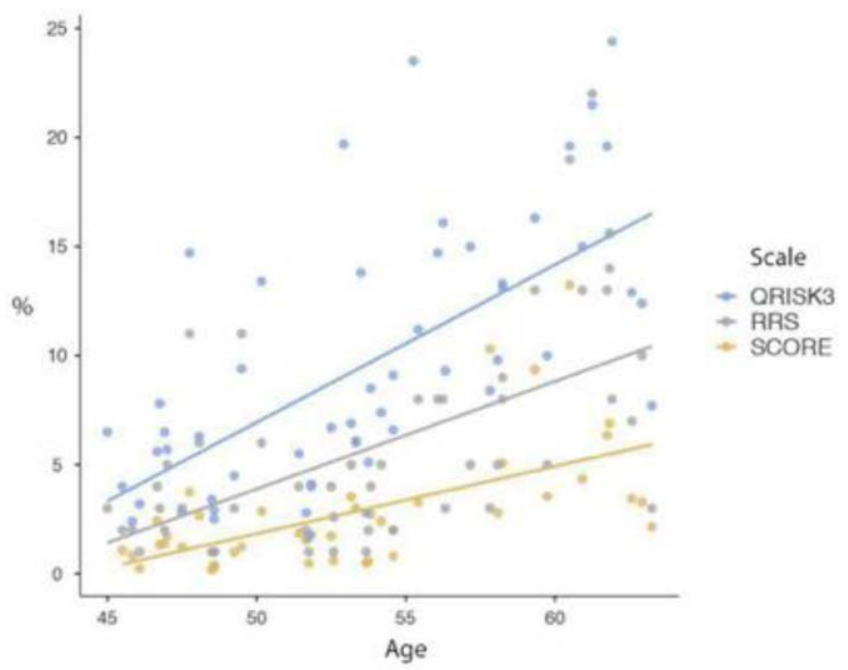

Figure 1. Cardiovascular risk evaluation indices in patients with axial spondyloarthritis, $\mathrm{n}=118$ for QRISK3, n=72 for SCORE and RRS.

Results: Mean age of the pts was $44.3 \pm 11.1$ years; $91(77.1 \%)$ pts were males, HLA-B27 positive $-83(70.3 \%)$ of the pts; mean disease duration $13.0 \pm 8.3$ years. Mean value of SCORE was $2.78 \pm 1.89 \%$, of RRS $-5.28 \pm 3.31 \%$, of QRISK3 $7.91 \pm 3.8 \%$ (figure 1). Cronbach's alpha for the scales was 0.873 .

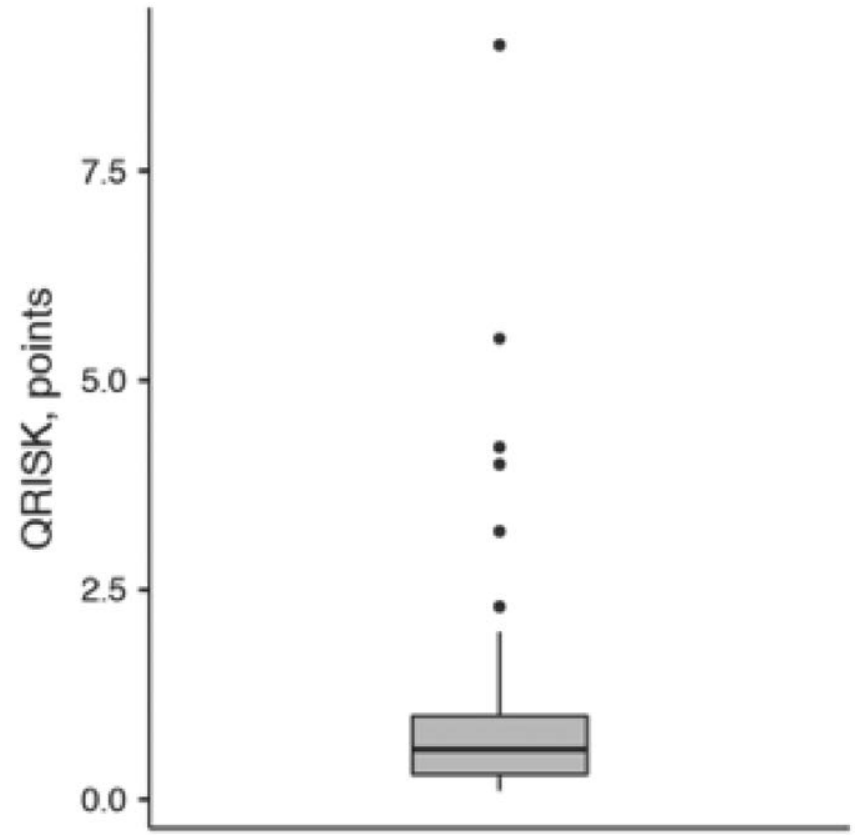

Figure 2. QRISK3 index in axSpA patients $25-40$ years old, $n=46$
High CVR ( $\geq 5 \%$ ) was found in $14(11,7 \%$ ) of the pts according to the SCORE, in $65(55,1 \%)$ of the pts according to the RRS, and in $81(69 \%)$ of the pts according to the QRISK3. Ranking of CVR severity did not match in SCORE and QRISK3 indices in $83.72 \%$ of cases, in SCORE and RRS - in $51.16 \%$ of cases, and in QRISK3 and RRS in $8 \%$ of cases. The SCORE index showed the lower values of the expected risk as compared to the QRISK3 and RRS (figure1).In axSpA pts at age $25-40$ years old $(n=46$, mean age $32.6 \pm 4.0$ years, males $36(78.3 \%))$, mean value of QRISK3 was $1.16 \pm 0.99 \%$; in 14 from $46(30.4 \%)$ of those pts increased CVR was registered (figure 2).

Conclusion: There was a discrepancy in the severity of CVR calculated using different rating scales in axSpA patients. The SCORE index showed lower values of CVR as compared to the QRISK3 and RRS, which hypothetically could be the consequence of CVR underestimation. QRISK3 demonstrated the highest CVR and was the only index useful in pts below 40 years old. To exclude hyper- or underestimation of CVR calculation more data abou CVR calculations and frequency of CV events, occurring in axSpA patients are needed.

Disclosure of Interests: Elizaveta Vasilenko: None declared, V Mazurov: None declared, Ruzana Samigullina: None declared, Anna Dadalova: None declared, Inna Gaydukova Grant/research support from: JSC BIOCAD, Speakers bureau: Pfizer, Novartis, AbbVie, JSC BIOCAD, Celgene, MSD, Sanofi DOI: 10.1136/annrheumdis-2020-eular.929

\section{SAT0394 CAN FECAL CALPROTECTIN PREDICT FUTURE DEVELOPMENT OF INFLAMMATORY BOWEL DISEASE IN AXIAL SPONDYLOARTHRITIS PATIENTS? - TREASURE REAL-LIFE DATA}

G. K. Yardımcı ${ }^{1}$, O. C. İçaçan ${ }^{2}$, G. Kabadayi ${ }^{3}$, B. Farisoğulları ${ }^{1}$, B. Armagan ${ }^{1}$, C. Bes ${ }^{2}$, S. Akar ${ }^{3}$, U. Kalyoncu ${ }^{1} .{ }^{1}$ Hacettepe University Faculty of Medicine, Rheumatology, Ankara, Turkey; ${ }^{2}$ University of Health Sciences, Bakırköy Sadi Konuk Research and Training Hospital, Rheumatology, Istanbul, Turkey; ${ }^{3}$ Izmir Katip Celebi University, School of Medicine, Rheumatology, Izmır, Turkey

Background: Patients with active inflammatory bowel diseases (IBD) fecal calprotectin (FC) levels are high and FC can be used for diagnosis [1].

Objectives: This study aimed to investigate whether fecal calprotectin levels could predict future development of IBD in axSpA patients.

Methods: This study was practiced in three centers using TReasure database and that are able to measure FC. Fecal calprotectin levels were measured in 137 axSpA patients as of September 2018 and FC level $\geq 200 \mu \mathrm{g} / \mathrm{g}$ was considered significant. All study subjects were evaluated for IBD symptoms (loose defecation, mucous diarrhea, bloody defecation, bloody diarrhea, abdominal pain, obstruction, or pseudo-obstruction) at beginning of the study and every 3 months for the first year. 25 RA patients and 24 healthy volunteers were included as a control group. Disease activity was evaluated by the ASDAS CRP, BASDAI $B A S F I$, erythrocyte sedimentation rate (ESR), C-reactive protein (CRP), visual analog scale (VAS)-pain, VAS-fatigue, and tender and swollen joint count for axSpA patients.

Results: This study included 137 axSpA patients and all patients followed for 1 year. Of the 137 axSpA patients $33.6 \%$ were females and median (Q1-Q3) age was of 43 years (33-50 years), median (Q1-Q3) disease duration was 8.9 years (5.0-13.9 years). The median (Q1-Q3) fecal calprotectin level was $48 \mu \mathrm{g} / \mathrm{g}$ $(30-122 \mu \mathrm{g} / \mathrm{g})$ and FC level was $\geq 200 \mu \mathrm{g} / \mathrm{g}$ in $23 / 137$ (16.8\%) in axSpA patients FC level was elevated in 15/24 (62.5\%) RA patients and none of the healthy volunteers. Patients median (Q1-Q3) BASDAI was 2.2 (1.0-3.6) / 1.4 (0.4-2.2) median (Q1-Q3) BASFI 1.55 (0.4-3.4) / 1.5 (0.3-3.0) and median (Q1-Q3) ASDAS CRP 1.63 (1.3-2.2) / 1.5 (1.3-1.9) at baseline and first year respectively and there was no difference regarding fecal calprotectin level. In 1 year follow-up $9(6.5 \%)$ patient had abdominal pain, $2(1.4 \%)$ had bloody defecation, $1(0.7 \%)$ had loose defecation and Crohn disease developed in an axSpA patient with high FC $(266 \mu \mathrm{g} / \mathrm{g})$ (Table 1). IBD occurrence rate was $0.73 / 100$ patient-year for all SpA patients, and IBD occurrence rate was $4.34 / 100$ patients year for SpA patients with $\geq 200 \mu \mathrm{g} / \mathrm{g}$ FC level.

Table 1. IBD symptom inquiry and development of IBD in the first year

\begin{tabular}{lc}
\hline & $\mathrm{n}(\%)$ \\
\hline Loose defecation & $1(0.73)$ \\
Mucous diarrhea & 0 \\
Bloody defecation & $2(1.45)$ \\
Bloody diarrhea & 0 \\
Abdominal pain & $9(6.56)$ \\
Obstruction & 0 \\
Pseudo-obstruction & 0 \\
Inflammatory bowel disease & $1(0.73)$ \\
\end{tabular}


Conclusion: In one year follow-up, IBD occurrence rate was $0.73 / 100$ patientyear, at a similar rate with DESIR cohort [2]. However, FC level may be a predictor for the development of IBD in SpA patients (occurrence rate 4.34/100 patients year). Further follow up duration and more patients may be needed to make conclusion in these field

References:

[1] Simioni, J., et al., Fecal Calprotectin, Gut Inflammation and Spondyloarthritis. Arch Med Res, 2019.50(1): p. 41-46.

[2] Wendling, D., et al., Effect of Gut Involvement in Patients with High Probability of Early Spondyloarthritis: Data from the DESIR Cohort. J Rheumatol, 2019.

Disclosure of Interests: Gözde Kübra Yardımcı: None declared, Ozan Cemal Içaçan: None declared, Gokhan Kabadayi: None declared, Bayram Farisoğulları: None declared, Berkan Armagan: None declared, Cemal Bes: None declared, Servet Akar: None declared, Umut Kalyoncu Consultant of: Abbvie, Amgen, Janssen, Lilly, Novartis, UCB

DOI: 10.1136/annrheumdis-2020-eular.6238

\section{SAT0395 SOCIAL ISOLATION IS INDEPENDENTLY ASSOCIATED WITH MORE SEVERE DISEASE IN AXIAL SPONDYLOARTHRITIS}

S. S. Zhao ${ }^{1,2}$, N. L. Harrison ${ }^{2}$, L. Peruffo ${ }^{2}$, N. Goodson ${ }^{1,2}$. $^{1}$ University of Liverpool, Liverpool, United Kingdom; ${ }^{2}$ Aintree University Hospital, Liverpool, United Kingdom

Background: Social isolation has negative impacts on health and wellbeing at different stages of life. It is associated with longer sickness absence and increased mortality in the general population [1]. Reducing social isolation is a growing governmental priority in many countries such as the UK. The effects of social isolation on patients with rheumatic diseases have not been studied. Objectives: To examine whether living alone impacts disease severity and quality of life among axial spondyloarthritis (axSpA) patients.

Methods: We conducted a single-centre cross-sectional study of consecutive patients meeting the ASAS axial SpA criteria in Liverpool, UK. Patients answered questionnaires including whether they lived alone, which we used as a proxy for social isolation. Disease assessment measures included BASDAI, spinal pain, BASFI, quality of life (EuroQol), global health and fatigue. We separately extracted self-reported anxiety or depression from the EuroQol questionnaire (as absent, moderate, severe) since it is an important associated factor. Patient characteristics were compared between patients who lived alone and those who did not, using descriptive statistics. The association between social isolation and each disease measure were assessed using multivariable linear models, adjusted for age, gender, post-code derived deprivation index, BMI, anxiety/ depression and smoking status.

Results: A total of 353 patients ( $68 \%$ male, mean age 46 years) were studied; $82 \%$ met the modified New York criteria for ankylosing spondylitis. 58 (16\%) patients reported living alone. These patients were older (49 vs 43 years, $\mathrm{P}=0.006$ ), more frequently male ( 83 vs $65 \%, \mathrm{P}=0.008$ ), and more frequently current smokers (53 vs $31 \%, p=0.009$ ). They were otherwise similar in the proportion meeting criteria for AS, HLA-B27 positivity, and BMI (Table 1). Self-reported anxiety or depression was not significantly different between the two groups. Regression models showed that patients living alone had 1 unit higher BASDAI, pain and BASFI than those who did not, independent of potential confounders (Table 2). Living alone was also associated with poorer quality of life, but not fatigue or global health.

Table 1. Patient characteristics compared according to whether they live alone.

\begin{tabular}{lccc}
\hline & Do not live alone & Live alone & P value \\
\hline $\mathrm{N}(\%)$ & $295(83.6 \%)$ & $58(16.4 \%)$ & \\
Mean age, years (SD) & $43.4(14.0)$ & $49.0(12.4)$ & 0.006 \\
Males, $\mathrm{n}(\%)$ & $192(65.1 \%)$ & $48(82.8 \%)$ & 0.008 \\
Meeting mNY criteria & $238(80.7 \%)$ & $48(82.8 \%)$ & 0.712 \\
HLA-B27 positive & $109(54.0 \%)$ & $25(71.4 \%)$ & 0.054 \\
Mean BMI, (SD) & $28.17(5.6)$ & $29.40(6.8)$ & 0.196 \\
Smoking status & & & \\
Current & $87(31.4 \%)$ & $30(52.6 \%)$ & 0.009 \\
Ex & $52(18.8 \%)$ & $8(14.0 \%)$ & \\
Never & $138(49.8 \%)$ & $19(33.3 \%)$ & \\
Self-reported anxiety or depression & $145(49.2 \%)$ & $22(38.0 \%)$ & 0.229 \\
Absent & $120(40.7 \%)$ & $27(46.6 \%)$ & \\
Moderate & $30(10.2 \%)$ & $9(15.5 \%)$ & \\
Extreme & $2(1,5)$ & $2(1,4)$ & 0.190 \\
Deprivation Index, median (IQR) & & & \\
\hline
\end{tabular}

Table 2. Impact of social isolation (living alone) on disease severity measures in axial spondyloarthritis.

\begin{tabular}{lc}
\hline BASDAI & $1.0(0.2$ to 1.8$)$ \\
Spinal pain & $1.0(0.03$ to 1.9$)$ \\
BASFI & $1.0(0.1$ to 1.9$)$ \\
Quality of life & $-0.13(-0.24$ to -0.02$)$ \\
Fatigue & $0.1(-0.7$ to 0.9$)$ \\
Global health & $-0.03(-0.8$ to 0.7$)$ \\
\hline
\end{tabular}

Data shown as coefficient $(95 \% \mathrm{Cl})$. Quality of life assessed using EuroQol. All other indices are on a scale of 0 (best) to 10 (worst).

Conclusion: Living alone - as a proxy for social isolation - was associated with more severe disease and poorer quality of life in axSpA patients, independent of depression and other confounders. Further studies are needed to examine the direction of causation, and whether lack of social support influences their ability to seek and/or benefit from healthcare provision.

References:

[1] Cornwell EY, Waite LJ. Social disconnectedness, perceived isolation, and health among older adults. J Health Soc Behav. 2009;50(1):31-48.

Disclosure of Interests: None declared

DOI: 10.1136/annrheumdis-2020-eular.885

\section{SAT0396 INFLUENCE OF SMOKING AND OBESITY ON THERAPEUTIC RESPONSE IN PATIENTS WITH AXIAL SPONDYLOARTHRITIS: A SYSTEMATIC LITERATURE REVIEW}

P. Zurita-Prada ${ }^{1}$, C. Urrego-Laurín ${ }^{1}$, C. Guillén-Astete ${ }^{1}$, V. Navarro-Compán ${ }^{2}$. ${ }^{1}$ Hospital HLA Universitario Moncloa. Universidad Europea de Madrid, Rheumatology, Madrid, Spain; ${ }^{2}$ Hospital La Paz, IdiPaz., Rheumatology, Madrid, Spain

Background: Biological therapies have substantially improved the prognosis of patients with Spondyloarthritis (SpA). However, a satisfactory clinical response is not achieved in all patients and it is essential for the clinician to identify all those factors that predict treatment response. Although they are supposed as unfavorable and potentially avoidable factors, the influence of smoking and obesity as predictors of treatment response in SpA is unknown.

Objectives: To determine if smoking and obesity are factors of worse therapeutic response in patients with axial spondyloarthritis (axSpA).

Methods: Systematic review of the literature in MEDLINE and EMBASE unti June 30, 2019 based on the PICO design method. Population $(P)$ : patients with axSpA. Intervention (I): smoking or obesity. Comparator (C): non-smokers and normal weight. Outcome $(\mathrm{O})$ : any of the response criteria currently validated for axSpA. A specific excel form was used for data collection, EndNote software for the management and organization of papers and the Oxford 2009 level for evidence evaluation.

Results: 1873 citations were recovered, 46 studies were selected for full-text review and 12 for data extraction: 6 for smoking and 6 for obesity. The design

\begin{tabular}{|c|c|c|c|c|c|}
\hline \multicolumn{6}{|c|}{$\begin{array}{l}\text { INFLUENCE OF OBESITY IN THE RESPONSE TO BIOLOGICAL THERAPY IN RADIOGRAPHIC } \\
\text { AND NON-RADIOGRAPHIC AXIAL SPONDYLOARTHRIIS }\end{array}$} \\
\hline Author & $\begin{array}{l}\text { Design. Country. } \\
\text { Total Patients. } \\
\text { Treatment. }\end{array}$ & $\begin{array}{l}\text { Patients } \\
\text { group }\end{array}$ & & Qutcomes & $\begin{array}{l}\text { Influence. } \\
\text { Evidence level. }\end{array}$ \\
\hline $\begin{array}{l}\text { Qttaniani } \\
2012\end{array}$ & $\begin{array}{l}\text { Longitudinal observational } \\
\text { (Retrospective cohorts) } \\
\text { France } \\
155 \text { patients; ITNE }\end{array}$ & $\begin{array}{l}\text { BMI } 25 \\
\text { BMI } 25-0 \\
\text { BMI } 30\end{array}$ & $\begin{array}{l}63 \\
54 \\
38\end{array}$ & $\begin{array}{l}\text { - } 6 \text { months: } \\
\text { BASDAI 50;VAS } \\
\text { 50; NSAID } 50\end{array}$ & $\begin{array}{r}\text { Yes } \\
2 b\end{array}$ \\
\hline $\begin{array}{l}\text { Gremese } \\
2014\end{array}$ & $\begin{array}{l}\text { Longitudinal observational } \\
\text { (Retrospective cohorts) } \\
\text { Italy } \\
170 \text { patients, ITNE }\end{array}$ & $\begin{array}{l}\text { BMI }<25 \\
\text { BMI } 25-0 \\
B M I>30\end{array}$ & $\begin{array}{c}92 \\
55 \\
23\end{array}$ & $\begin{array}{l}12 \text { months: } \\
\text { BASDAI50; BASDAI }\end{array}$ & $\begin{array}{l}\text { Yes } \\
2 b\end{array}$ \\
\hline $\begin{array}{l}\text { Micheroli } \\
2017\end{array}$ & $\begin{array}{l}\text { Longitudinal observational } \\
\text { (Retrospective cohorts) } \\
\text { Switzerland } \\
624 \text { patients, iTNE } \\
\end{array}$ & $\begin{array}{l}\text { BMI }<25 \\
\text { BMI } 25-0 \\
\text { BMI }>30\end{array}$ & $\begin{array}{r}332 \\
204 \\
88 \\
5\end{array}$ & $\begin{array}{l}-6 \text { months: } \\
\text { ASAS 40; ASAS } \\
\text { remission; BASDAI } \\
\text { 50; ASDAS }\end{array}$ & $\begin{array}{l}\text { Yes } \\
2 \mathrm{~b}\end{array}$ \\
\hline \begin{tabular}{|l} 
Rosas \\
2017
\end{tabular} & $\begin{array}{l}\text { Cross-sectional } \\
\text { Spain } \\
57 \text { patients, TNE }\end{array}$ & $\begin{array}{l}\text { BMI }<25 \\
\text { BMI } 25-0 \\
\text { BMI }>30\end{array}$ & $\begin{array}{l}17 \\
25 \\
15\end{array}$ & $\begin{array}{l}\text { BASDAI; ASDAS; } \\
\text { BASFI }\end{array}$ & $\begin{array}{c}\text { Yes } \\
4\end{array}$ \\
\hline $\begin{array}{l}\text { Hernandez- } \\
\text { Breilie } \\
2019\end{array}$ & $\begin{array}{l}\text { Prospective observational } \\
\text { Spain; Holland } \\
180 \text { patients, iTNE }\end{array}$ & $\begin{array}{l}\mathrm{BMI}<25 \\
\mathrm{BMI}>25\end{array}$ & $\begin{array}{r}78 \\
102\end{array}$ & $\begin{array}{l}1 \text { year: } \\
\triangle \text { BASDAI } \geq 2 \\
\triangle \text { ASDAS } \geq 1.1 \\
\text { Clinical remission }\end{array}$ & $\begin{array}{l}\text { Yes } \\
2 \mathrm{~b}\end{array}$ \\
\hline $\begin{array}{l}\text { Hernandez } \\
2019\end{array}$ & $\begin{array}{l}\text { Longitudinal observational } \\
\text { Spain } \\
147 \text { patients, ITNE }\end{array}$ & $\begin{array}{l}\text { BMI }<25 \\
\text { BMI 25-0 } \\
\text { BMI }>3015 \\
\text { Not reported }\end{array}$ & \begin{tabular}{l|l}
27 & \\
61 & $t$ \\
30 & $y$ \\
29 &
\end{tabular} & $\begin{array}{l}\text { - Withholding of } \\
\text { treatment after } 5 \\
\text { years of onset }\end{array}$ & $\begin{array}{l}\text { No } \\
2 b\end{array}$ \\
\hline
\end{tabular}

